\title{
Economic and trade relations between Poland and China since 2004
}

\author{
Krystyna Palonka
}

Published online: 26 November 2010

(C) Springer-Verlag 2010

\begin{abstract}
The recent economic recession over much of the developed world may, at least partly, redirect Chinese activity towards regions different from those traditionally at the centre of Chinese interests. One such area is the eastern Baltic, in general, and Poland, in particular, as a large economy in the region. While there have been some political tensions in recent years, this article emphasises that cultural and economic relations have been developing significantly faster in the last few years, with mutual recognition increasing. While, not unexpectedly, there is still an imbalance of the quantity goods traded, and of a divergence in the categories of such goods, there are good reasons for optimism as recent high-level visits between both countries have shown. Looking at such factors as foreign direct investment growth and stimulus packages, this short descriptive, rather than analytical overview, presents a case for an optimistic scenario even if it does indicate a background of some uncertainty in the global context impacting upon growth of relations between the two countries.
\end{abstract}

In an increasingly networked, transregional global economic, political and even social context (Van Langenhove 2010), ties between countries become emblematic of region-to-region relations, but also retain the edge of the national. One pertinent example is offered by a consideration of contemporary political and economic relations between Poland and China which have of course, to a certain extent, been determined by the great and rapid changes in both countries towards the end of the twentieth century. China's role in international trade, its increasing need for natural resources, growing currency reserves and aspiration to ascend to the most advanced technological levels make imperative its coherence into global networks. Poland too has seized the opportunities and moved proactively to counter the challenges of this new world order, voicing an agenda composed of Europeanised, national, historical and

K. Palonka $(\bowtie)$

Centrum Studiow Polska-Azja, Warsaw, Poland

e-mail: krysiapalonka@gmail.com 
geostrategic elements. A 2008 survey found that Poles were generally optimistic about globalisation: $59 \%$ (just above the EU average) saw it as a means of fostering economic growth; the highest percentage of any country surveyed (EU member states and a few others) saw globalisation as a means of attracting foreign investment, and the country was third lowest with respect to the perception of globalisation as a threat (only Germany and Bulgaria were lower) (European Commission 2008).

Poland was one of the first countries to recognise the People's Republic of China in 1949, and this recognition established a course of generally good relations. Early agreements were reached on copper mining and the establishment of "Chipolbrok", the Chinese-Polish Joint Stock Shipping Company, in 1951 (see pp. 322-323 in Levi 1953), was the first such external Chinese joint venture. The company now has regular sailings from Antwerp through the Suez Canal and via Singapore on to Shanghai, Dalian, Xingang and Busan in Korea. In a speech in Shanghai during an October 2008 visit, Polish Prime Minister Donald Tusk characterised PolishChinese relations as emanating from a "natural confidence resulting from tradition and mutual respect" (The Chancellery of the Prime Minister 2008). As a sign of such an engagement, Chinese President $\mathrm{Hu}$ Jintao had been among the first heads of state to visit Poland after its EU accession in 2004 (People's Daily Online 2004). "Mutual understanding"- - so Tusk — was a precondition for and facilitator of economic relations, and thus, one might infer, reciprocal positive perceptions were not to be sidelined in importance, even in a globalised world of commodities. Good will and the will to trade are mutually dependent.

The legacy of the recent past (see p. 41 in Sandschneider 2002), divergent views on some issues (Tibet, the Dalai Lama for example) and "anticommunist" reflections may have impinged upon some perceptions of China in Poland, with unfortunate repercussions in some circles; even so, the track record has been on the positive side. While an opinion poll found that "looking from the outside," Europeans saw Poland as a "sympatyczny" country with potential, even if it was difficult to say anything concrete ("cokolwiek konkretnego") about it (Smoczynski 2009), the image of the country seems to have greater outline in China.

The recent economic recession over much of the developed world may, at least partly, expand Chinese activity globally, and thus herald a greater attention to the Baltic region. Poland is one of the previous European centrally planned economies which is now finding and developing niche markets for itself, moving to generate new technology, at a time when China is similarly expanding its range of exports, and thus when intraindustry trade at a higher level of the value-added chain is possible.

There are at least signs of a more general renewed interest from both Europe and East Asia in a proliferation of pathways and discursive approaches to the relationships between China and the Baltic, for example through the Riga-based "silk roads" project (Stockholm School of Economics 2009) and the proposed "new silk [rail-]road" itself, noted elsewhere in this issue. Polish EU accession in 2004 also increased Chinese interest in the country, as it is seen potentially as a bridgehead to eastern EU markets, with the relative size of its economy, and its pivotal location in both Central and Eastern Europe and with respect to the Baltic, traditionally an "unfortunate geographical position" now somewhat of an asset (see p. 151 in Morrison 1978). Added to such a list might be the country's historical associations with socialist East Asia (see pp. 117-121 in Chen 1987), even if of course the tenor of the China-Eastern 
European relation was modulated by the partner's respective relations with the Soviet Union, again showing the pivotal role of that region in Baltic-East Asian relations.

While, not least in recent years, there have been certain political tensions, cultural and economic relations have been developing significantly faster in the last few years. Several agreements, including one for the historically important copper mining industry, were signed on the occasion of President Hu's 2004 visit. There are at least four strong centres of Chinese language studies in Poland and four Confucius Institutes, in Krakow (established 2007), Poznan, Wroclaw and Opole (founded in 2008). The unexpected success of the Polish pavilion at the 2010 Shanghai Expo raised some hopes for increased mutual interest and better relations.

In the last 3 years, diplomatic activity as a spur to trade has been quite marked, especially in economic matters. Chinese Vice Premier Zeng Peiyan visited Poland in 2008, at which time the trade deficit was discussed. In 2007 and 2008, that is before the main onset of the financial crisis, China exported to Poland goods to a value of some 14 times that of Poland's exports to China; while this trade gap narrowed a little in 2009 and Polish exports rose quite significantly, the gap was still appreciable (Table 1, to be discussed in more detail below). Clearly this is partly a consequence of the relative sizes of the two economies, and Chinese enterprise is of value in Poland's own development, at the meetings, the possibility of using Chinese enterprises and labour in construction works improving Polish infrastructure and stadia was discussed. Shortly after that visit, two significant export contracts were signed by Polish enterprises, one for delivery of 40,000 tonnes of copper for the Chinese Minmetals Corporation (showing once more the traditional strength of that sector of Polish industry for trade with China) and the other for delivery of helicopters for Jiujiang Red Eagle Corporation. Infrastructure projects, including highway construction, were accepted in 2009 and negotiations are in progress concerning Chinese stakes in the Polish seaports Gdansk and Szczecin. A delegation from the Chinese Ningxia Hui Autonomous Region and the State Commission for Development and Reforms was received by the Polish Ministry of Economy to establish cooperation with the Polish coal mining industry, cooperation from which the Polish company Kopex benefitted. Such enterprises and joint ventures should help lessen the trade deficit somewhat.

In September 2008, Polish Deputy Prime Minister Waldemar Pawlak visited China with the major goal to enforce Chinese-Polish economic co-operation and mutual investments in particular (Pawlak 2008). He was received by President $\mathrm{Hu}$ Jintao and Prime Minister Wen Jiabao. He also met the Minister of Trade and chief executives of big Chinese corporations such as the China Railway Engineering Group and Lenovo. With the governor of the China Development Bank, he discussed the possibilities of financing big mutual investment projects in Poland.

Concomitant to such diplomatic activity, trade relations between the two countries have been steadily improving. Data from the Polish Embassy in Beijing show that turnover growth during 2006-2007 was estimated as 49\%. Poland is the biggest Chinese partner in trade in Central Europe, considering general turnover and imports and the second biggest-after Hungary-in export terms. In 2007, the Polish Embassy noted that total trade reached some 16 billion euros; this figure was holding generally steady through to 2009 , although the financial crisis has led to a drop on both sides (People's Daily Online 2009). 


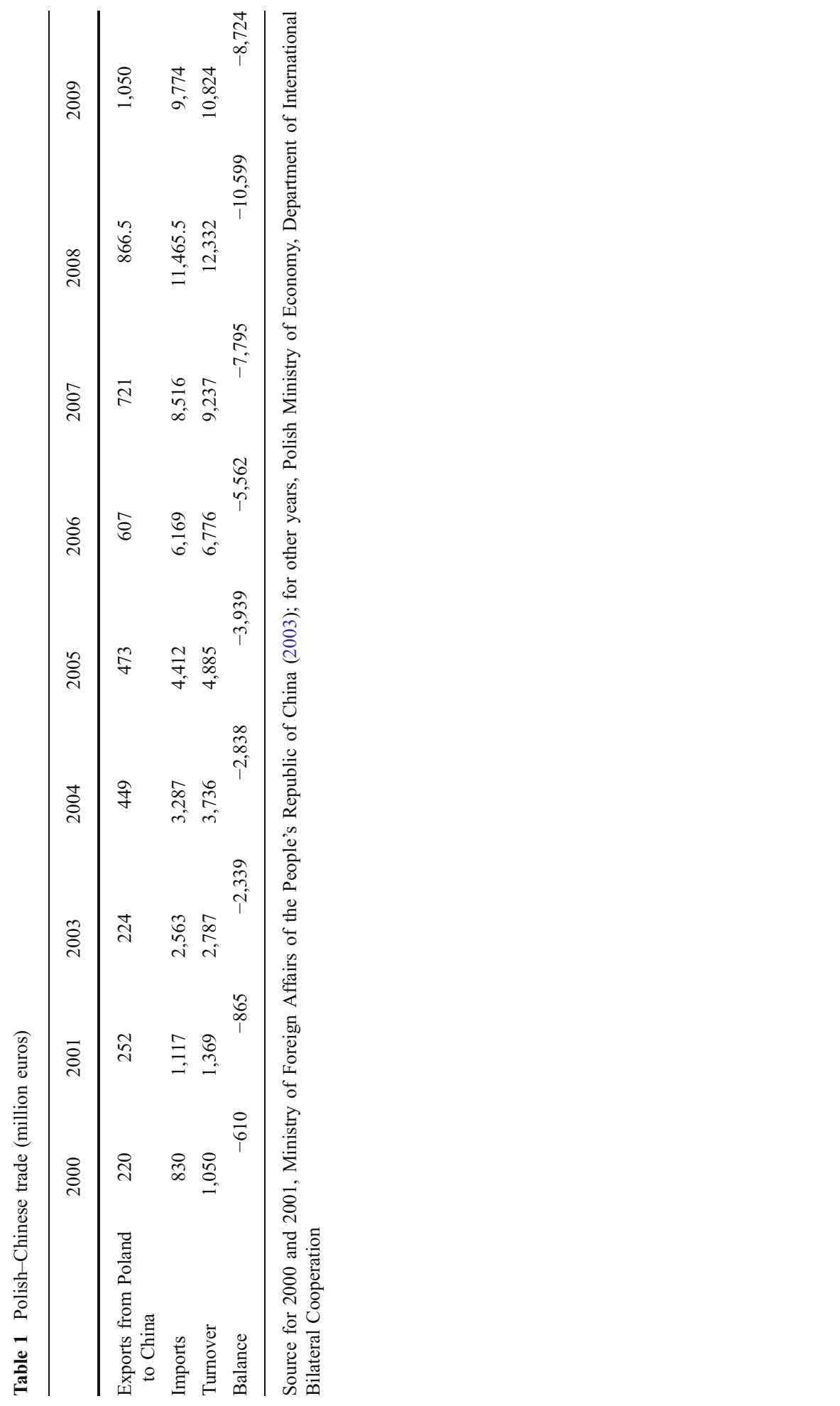


Recent growth of total trade has been significant, but considering the amounts in question it is still far too modest, and due to a decrease in import value and of course the financial crisis, it even slowed down in 2009. Polish imports from China account for $9.3 \%$ of total imports to Poland while exports from Poland to China make only $1.1 \%$ of total Polish exports. The imbalance in trade between the two countries is therefore significant, with exports from Poland to China roughly ten times smaller than Chinese imports into the country (Table 1).

Just before Poland's EU accession in 2004, the trade deficit started to increase dramatically, as the country geared up for its new alignment and the economic and general cultural ambience of global trade competition with an EU context. In 2008, the deficit comprised $42 \%$ of the total Polish trade deficit, but decreased in 2009 as a consequence, no doubt, of the global downturn. In the meantime, China became Poland's second trade partner (after Germany). Intraregional trade is still therefore of great significance in this, the latest period of globalisation; while Poland's intra-EU trade deficit shrank somewhat in the 2 years after EU accession, but doubled overall in 2004-2008, its extra-EU deficit grew some 2.5 times, largely because of imports from China and Russia (see p. 267 in Eurostat 2009); however, that, between 2004 and 2008, the trade deficit with the latter grew more than with the former gives some perspective to the relative importance of both such transregional trade and of Russia in the trajectory some papers in this issue attempt to trace.

Significantly, exports to China have increased five times while imports only four times during the last 5 years; however, the proportion of low-value-added products among Polish exports to China is relatively high, with raw materials, minerals and simple components being the major commodities offered so far for the Chinese market (see Table 2). According to EU regulations, some anti-dumping taxes were imposed on shoes and some agricultural products. Thus low-end value-added commodities lost some market share also in Poland.

The biggest exporter from Poland is KGHM (Kombinat Górnictwa i Hutnictwa Miedziowego) Polska Miedź SA (copper mining industry), a major global player in

Table 2 Share of main commodities in Chinese-Polish trade

\begin{tabular}{lcccc}
\hline Categories & $\begin{array}{l}\text { Exports (2006) } \\
\text { from Poland (\%) }\end{array}$ & $\begin{array}{l}\text { Exports } \\
(2009)(\%)\end{array}$ & $\begin{array}{l}\text { Imports (2007) } \\
\text { into Poland (\%) }\end{array}$ & $\begin{array}{l}\text { Imports } \\
(2009)(\%)\end{array}$ \\
\hline Metallurgy, basic metals & 33 & 38.9 & 10 & 5.5 \\
$\begin{array}{l}\text { Machinery, electric/electronic } \\
\text { equipment }\end{array}$ & 29 & 25.3 & 55 & 54.7 \\
Chemicals & 24 & 13 & 6 & NA \\
Minerals & 4 & NA & 0 & NA \\
Food and agriculture & 3 & NA & 3 & NA \\
Forestry, timber, paper & 2 & NA & 1 & NA \\
Ceramics & 1 & NA & 3 & 13 \\
Light industry & 1 & NA & 7 & 23.7 \\
Others & 2 & 22.8 & & NA \\
\hline
\end{tabular}

Source: Polish Ministry of Economy, Department of International Bilateral Co-operation 
the copper mining and silver extraction industries. In October 2010, the company set up a copper trading company in Shanghai to extend its participation in the Chinese market (Trading Markets.com 2010). Others are chemicals, fertiliser and coal mining industries. Still the trend does show upward movement along the export value chain. There are also new prospects for specialised aircraft industry exports. There is therefore a movement in Polish exports towards more processed goods, a major explanation of which is the recovering exports of coal mining equipment. Conversely, the most important commodities imported from China are computers, cell telephones, electronic gadgets and electronic components, as Poland looks for comparatively cheap products necessitated by the increased importance placed in the knowledge economy on ICT in trade competition. Chinese goods imported into Poland are therefore much more sophisticated than those exported. Many small and medium size companies in Poland are looking for technologically advanced but cheaper products and components on the Chinese market.

It is estimated that about 14,000 Chinese companies of different sizes and specialties were operating in Poland but only about 1,100 Polish companies operating on Chinese markets. Chinese strategy is motivated by central aims, among which are sourcing mineral resources, prudent investment of its foreign currency surplus and promoting its exports and brands, including perhaps China as itself a brand concept. This disproportion also suggests that there is still too little interest from Polish businesses to operate on the Chinese market. ${ }^{1}$ As mentioned above, traditional markets in Central and Eastern Europe and the German market still are of more marked importance in general business perception.

The special privileges for foreign investors in Polish Special Economic Zones are subjects of frequent presentations; such zones show an openness to the economy, help foster regional development and - as at Koszalin in northern Poland (Beijing Review.com.cn 2007) — offer the advantages of "economic safety, highly-qualified cadres and an attractive incentive system" (Polish Information and Foreign Investment Agency 2009). The Polish Embassy in Beijing for example has organised many events with eminent Chinese businessmen, including among others, Lenovo computers, Minmetals (non-iron metals processing and trade), Nuctech, Huawei (IT equipment), the China Railway Engineering Group and China Overseas Engineering Corporation (construction), ZTE Corporation (telecommunications) and Shandong Tagao Mining Equipment Corporation, co-investor with Polish company Kopex for manufacturing coal mining equipment. Joint ventures and partnerships sustained by a political and diplomatic commitment are the norm here.

\section{FDI inflows from China and FDI outflows from Poland}

General figures for foreign direct investment inflows are presented in Table 3 which shows the still relatively limited significance of Chinese investments in Poland. Chinese investments into Poland are comparably small but increased some 30-fold in the first 4 years of Poland's membership in the EU. According to the Polish Ministry

\footnotetext{
${ }^{1}$ Data are only available through customs statistics and tax authorities and are difficult to obtain. Information is from Ms. Katarzyna Kaniewska at the KIG (Polish National Chamber of Commerce).
} 
Table 3 Inflow of FDI into Poland 2004-2007

\begin{tabular}{lcrrr}
\hline Region/country & \multicolumn{1}{c}{2004} & \multicolumn{1}{c}{2005} & \multicolumn{1}{c}{2006} & \multicolumn{1}{c}{2007} \\
\hline World & $10,304.8$ & $8,259.9$ & $15,575.9$ & $16,582.1$ \\
EU & $9,052.1$ & $6,783.2$ & $13,362.3$ & $12,303.9$ \\
Japan & 150 & 239.3 & 253.7 & 191.6 \\
China & 2.1 & 36.6 & 20.0 & 62.0 \\
\hline
\end{tabular}

Data from the National Bank of Poland (in million euros) (National Bank of Poland 2007)

FDI foreign direct investment

of Economy, the cumulative amount of Chinese investments in Poland reached some 270 million euros at the end of 2009. Among the biggest investors were TTL Polska (LCD TV sets; about 80 million euros), GD (Guangdong) Poland, which runs the Euroazjatyckie Centrum Handlowe wholesale distribution centre near Warsaw (33 million euros) and Min Hoong Development (real estate in Warsaw and Sopot; some 33 million euros). As its name ("Euro-Asiatic Business Centre") implies, GD's centre caters to a cross-section of firms, of a total of about 800, 150 are Chinese, the others including Turkish, Indian and Vietnamese; the majority import clothing, shoes and other basic manufactured goods. While the business potential is clearly there, areas like non-invoiced imports and illegal immigration have raised concerns in some quarters (see Sal 2008).

According to the Polish Ministry of Economy, the amount of Polish investments in China has reached some 170 million euros, the biggest investors being in shipping and other transportation (for example Chipolbrok) machinery (for example, the Huaibei Long Po Electrical Company, a joint venture with Polish companies Kopex and Zwar) and chemicals.

\section{Elements of the Polish strategy}

According to views of Polish high officials of the Ministry of Foreign Affairs, there have been two major currents in the country's attitude towards China. The first is the so-called "dedication to ethical ideas", foregrounding such issues as human rights, freedom of minorities, Tibet and Taiwan and the style of government. The second is a pragmatic attitude which acknowledges the growing economic and political significance of "rising China". The more pragmatic vision for future relations with China generally takes into consideration the disproportion in capacity and size between the two countries and thus indicates the necessity of "acting together" either within the European Union as a whole or with other European (EU) Emerging Economies more specifically. Such a vision also underlines the importance of a more open policy towards China. It is time for the encouragement of Chinese involvement in the Polish economy, supporting exchange in education and taking advantage of the prevailing world financial and economic uncertainty that may make China think of a shift towards what may be considered not so developed markets. 


\section{Prospects for Chinese-Polish economic relations}

Pre-Poland's EU accession, bilateral relations between two countries had been regulated by a range of related measures, including those on avoiding double taxation (1988), sanitary protection (1994 and 1997), scientific and technological cooperation (1995) and intellectual property rights (1995) which is still not in operation (see Leśniewski 2007). Since 2004, and even more so since the Lisbon Treaty of 2009, Polish-Chinese relations - especially perhaps those with regard to trade - are to be structured also within prevailing EU policies, leading off also perhaps from the agreement on mutual economic co-operation and the establishment of a mutual commission of economic co-operation with respect to European Union regulations from June 2004 (in operation from April 2005).

In this light, the Polish economic relation strategy with China follows three major guidelines. First, Polish exporters are advanced in order to reduce the enormous gap between exports and imports; second, Chinese direct investments in Poland are encouraged; and third, conversely. Polish enterprises are promoted to invest in China. The elements of this strategy are supported by the advantages of the Polish economy, among which are its geographical location in central Europe, costeffectiveness, human resources (relatively well-educated labour) and support from EU Structural Funds. Since, as noted above, Poland is projected as a "Gateway to Europe" or the bridgehead for future penetration of more economically advanced European countries, it is the general destination (i.e. the EU) rather than the more specific regional location (i.e. in Central and Eastern Europe, the Baltic) which is being foregrounded, a sign of the coalescence of the subregional into the larger macroregion in business and investment perceptions.

National institutional frameworks are essential for the growth of trade relations and to act in consort with the wider regional including EU level. In Poland, major institutions monitoring and promoting Poland-China relations are the relevant departments in the Polish Ministry of Foreign Affairs and the Ministry of Economy (the Departament Miedzynarodowej Wspótpracy Dwustronnej, Department of International Bilateral Cooperation), the Polish Agency of Information and Foreign Investments (PAIiIZ) and the National Chamber of Commerce (Krajowa Izba Gospodarcza, KIG). Under the umbrella of KIG, there is a separate Polish-Chinese Chamber of Commerce, established in 2007.

PAIiIZ (Polska Agencja Informacji i Investycji Zagranicznych) helps investors enter the Polish market with the necessary administrative and legal procedures and is supported by a national network of regional Investor Service Centers which work in close cooperation with the voivodship (provincial) marshals responsible for the promotion of the voivodship. In 2006, during the 12th session of the Polish-Chinese Common Committee for Economic Cooperation, a memorandum concerning mutual promotion of investments was signed between PAIiIZ and the China International Investment Promotion Agency. Arising from this session, two working groups were set up to look into measures for removing barriers impeding mutual and reciprocal foreign investments.

The Polish National Chamber of Commerce, KIG, established in 1990 incorporates 140 regional and industry chambers and aims to support negotiations with the government and to promote Polish business abroad. For example, a December 2008 
KIG Poland-China seminar in Warsaw, attended by delegates from ten large Chinese conglomerates, many from Shanxi province, was helpful in promoting mutual cooperation and an optimistic atmosphere. Such commitment institutions are necessary in cementing bilateral cooperation, whether in business or politics.

In 2000, a credit agreement between the two countries was signed at an intergovernmental level. It was supposed to support mutual ventures and initially it was reserved for environmental protection only, but subsequently other industries were allowed to benefit (namely construction, infrastructure, mining and power generation). First contracts are pending realisation and the primary amount of total credit was increased to some 400 million euros.

As a consequence of the global economic downturn, China and Poland put in place economic stimulus measures (the latter under EU auspices). Such packages, of course common in many countries, could well create favourable conditions for increased cooperation in the near future and could include infrastructural and sustainable development. China's November 2008 package amounts to some $14 \%$ of the 2008 GDP and includes public housing improvements and more money for education and health (China's Economy 2008). This corresponds with the package of Poland's infrastructure and regional development co-sponsored by EU funds. Smaller in scope, it may create very favourable opportunities for the exchange of experiences, resources and mutual deals.

These measures, especially perhaps on the Chinese side (because of their sheer size), give an extra window of opportunity for some companies not only in the construction, pharmaceutical and environmental protection business but also in services and education. A consistent view for divergent perceptions, an awareness of the importance of good relations and of the prospects of a long-term business partnership are important factors in turning such opportunities into successes, and social learning can be advanced by such commitment institutions as mentioned above. However, there are still several uncertainties which may impact upon this success, for example cultural perceptions (in the wide sense of an environment in which decisions are taken), the consequences of Poland's joining the euro in the future, the comparative size difference, macroeconomic conditions (Haase et al. 2008) and the fluidity or fungibility of capital. This last is both an asset and a liability (indeed, as one of the "four mobilities" of the EU); however, to say that these concerns are intractable would be a denial of history and an expression of an undue pessimism unwarranted in the light of the trajectory I have attempted to trace in this short descriptive overview.

\section{References}

Beijing Review.com.cn (2007) Courting Chinese investors [interview with Polish Ambassador to Beijing Krzysztof Szumski]. http://www.bjreview.com.cn/qanda/txt/2007-08/24/content_73799.htm. Accessed 4 Nov 2010

Chen L (1987) The Soviet Union and Eastern Europe. In: Zhang P, Huenemann RW (eds) China's foreign trade. Oolichan, Lantzville, pp 110-121

China's Economy (2008) The economist. Vol. 390. November 13. http://www.economist.com/node/ 12606998/print. Accessed 19 Nov 2010

European Commission (2008) Eurobarometer 69. 2 The Europeans and globalization http://ec.europa.eu/ public_opinion/archives/eb/eb69/eb69_globalisation_en.pdf. Accessed 4 Nov 2010 
Eurostat (2009) External and intra-European union trade statistical yearbook: data 1958-2008. Publications Office of the European Union, Luxembourg

Haase E, Miglans M, Nabradi J (2008) Chinese outbound FDI: current and future role based on the example of Hungary, Latvia and Poland. NHH, Bergen

Leśniewski S (2007) Gospodarka Chin i polsko-chińskie stosunki gospodarcze [The Chinese Economy and Polish-Chinese economic relations]. http://www.bizneschiny.pl/index.php?option=com_content\&task= view\&id=450\&Itemid=2. Accessed 19 Aug 2010

Levi W (1953) Modern China's foreign policy. University of Minnesota Press, Minneapolis

Ministry of Foreign Affairs of the People's Republic of China (2003) Bilateral relations [Poland]. http:// www.mfa.gov.cn/eng/wjb/zzjg/xos/gjlb/3210/. Accessed 3 Nov 2010

Morrison JF (1978) The foreign policy of Poland. In: Kuhlman JF (ed) The foreign policies of Eastern Europe: domestic and international determinants. Sijthoff, Leiden, pp 129-165

Narodowy Bank Polski [National Bank of Poland] (2007) Aneks Statystyczny [Statistical annex]. www. nbp.pl/publikacje/zib/ZIB 2007 aneks.pdf. Accessed 19 Aug 2010

Pawlak W (2008) Poland is open to the East-statement of Polish deputy prime minister and minister of the economy. Pol Mark 7-8

People's Daily Online (2004) Poland pledges active efforts to help build EU-China relations. http:// english.peopledaily.com.cn/200406/09/eng20040609_145704.html. Accessed 9 June 2004

People's Daily Online (2009) Financial crisis may hamper expected increase in Poland-China trade. http:// english.peopledaily.com.cn/90001/90776/90883/6608187.html. Accessed 5 Aug 2010

Polish Information and Foreign Investment Agency (PAlilZ) (2009) Understanding on Koszalin's economic promotion. http://www.paiz.gov.pl/nowosci/?id_news=2166. Accessed 4 Nov 2010

Sal A (2008) China Wolka. Polityka 9(2643) 1 March

Sandschneider E (2002) China's diplomatic relations with the States of Europe. In: Edmonds RL (ed) China and Europe since 1978: a European perspective. China Quarterly Special Issues, Cambridge, pp 33-44, New Series No. 2

Smoczynski W (2009) Polska: kraj bez twarzy [Poland: a faceless country]. http://www.polityka.pl/kraj/ analizy/295379,1,nasz-wizerunek-za-granica.read. Accessed 4 Nov 2010

Stockholm School of Economics in Riga (2009) Silk road project. http://www.sseriga.edu.lv/node/415. Accessed 26 Aug 2010

The Chancellery of the Prime Minister (2008) Prime Minister: good economic relations China: our key to success. http://www.premier.gov.pl/en/press_centre/news/id:2354/. Accessed 3 Nov 2010

Trading Markets.com (2010) KGHM adds ante on China market. http://www.tradingmarkets.com/news/ stock-alert/kghmf_kghm-adds-ante-on-china-market-1271284.html. Accessed 3 Nov 2010

Van Langenhove L (2010) Egmont paper 36. The EU as a global actor in a multipolar world and multilateral 2.0 Environment. Academia, Ghent 